УДК 351:338.4:502

DOI: 10.35340/2308-104X.2019.82-1-01

\section{АНАЛІТИЧНЕ ЗАБЕЗПЕЧЕННЯ ДЕРЖАВНОЇ ПОЛІТИКИ РОЗВИТКУ МОРСЬКИХ ПОРТІВ УКРАЇНИ}

ГРИШОВА І. Ю.,

доктор економічних наук, професор, помічник-консультант

депутата Верховної Ради

України, ДЯЧЕНКО О. П., кандидат економічних наук, доцент, Одеський державний аграрний університет

\section{ANALYTICAL PROVISION OF THE STATE POLICY OF DEVELOPMENT OF MARINE PORTS OF UKRAINE}

\author{
GRYSHOVA I., \\ Doctor of Economics, Professor, \\ Assistant Consultant to the \\ Deputy of the Verkhovna Rada \\ of Ukraine, \\ DIACHENKO O., \\ Candidate of Economic Sciences, \\ Associate Professor, \\ Odessa State Agrarian University
}

В статті проаналізовано майновий стан та результати діяльності морських портів з переробки вантажів в розрізі їх номенклатури. Також визначено структуру перевезень вантажів через окремі морські порти, щуо входять до складу Державного підприємства «Адміністрачія морських портів України» та динаміку їх діяльності. Розраховано фінансові результати діяльності державного підприємства, щзо здійснює управління державним майном в морських портах та на їх основі обтрунтована необхідість впровадження реформ морського господарства із залученням приватних інвестицій.

Ключові слова: морські порти, аналітичне забезпечення, вантаж, державна політика, державне підприємство.

$B$ статье проанализировань имущественное положение $u$ результаты деятельности морских портов по переработке грузов в разрезе их номенклатуры. Также определена структура перевозок грузов через отдельные морские порты, входящие в состав Государственного предприятия «Администрация морских портов Украины» и динамика их деятельности. Рассчитань финансовые результать деятельности государственного предприятия, осуществляющего управление государственным имуществом в морских портах и на их основе обоснована необходимость реформ морского хозяйства с привлечением частных инвестиций.

Ключевые слова: морские порты, аналитическое обеспечение, груз, государственная политика, государственное предприятие.

The article analyzes the property status and results of the activity of seaports for cargo processing in terms of their nomenclature. The structure of cargo transportation through separate seaports that are part of the State Enterprise "Administration of Seaports of Ukraine" and the dynamics of their activities is also defined. The financial results of the state enterprise, which 
manages the state property in the seaports, are calculated, and based on these, the necessity of introducing maritime reform with the attraction of private investments is grounded.

Keywords: sea ports, analytical provision, cargo, state policy, state enterprise.

Постановка проблеми. Сучасний розвиток морських портів, що $\epsilon$ важливою складовою транспортних перевезень, неможливий без корінного оновлення матеріально-технічної бази, що викликає необхідність залучення приватних інвесторів, адже ресурсів держави для цього не вистачає. Державна політика розвитку морських портів має бути спрямована на створення прозорої системи державно-приватного партнерства, що дозволить приватному сектору економіки інвестувати кошти в модернізацію та будівництво портових об'єктів державного значення.

Відсутність забезпечення всім суб'єктам рівного доступу до об'єктів портової інфраструктури однозначно гальмує розвиток морських портів України. Однак морські порти й підприємства, особливо державної форми власності, що у них працюють, нині недостатньо конкурентоспроможні, що викликано значним зносом основних засобів, що задіяні в переробці вантажів.

Аналіз останніх досліджень $і$ публікацій. Дослідження питань державної політики розвитку морських портів України висвітлювалось у наукових розробках зарубіжних та вітчизняних вчених, зокрема: Т. О. Цабієва - основи забезпечення сталого функціонування і розвитку морських портів України [1], В. М. Мірошком визначено засади стратегічного планування економічного розвитку вантажних портів України [2], С. В. Ільченко - організаційноекономічні основи інституціонального реформування морських портів [3], О.В. Меркт обгрунтовано методичні засади стратегії розвитку морських торговельних портів у конкурентному середовищі [4], О. О. Карпенко та Г. Ю. Продченко - здійснили аналіз транзитних перевезень вантажів через морські торгівельні порти України [5]. Механізми державної стратегії детінізаії національної економіки, їх дієвість та ефективність розглянуто в наукових працях Гришової І. Ю., Дяченко О. П. [6-8] та інших.

Проте в умовах глобалізації світової економіки та поширення інтеграційних процесів актуалізується необхідність в дослідженні механізмів державної політики стосовно підвищення ефективності функціонування морських портів та їх аналітичного забезпечення, що потребує грунтовного аналізу стану та результатів діяльності за останні роки функціонування Державного підприємства «Адміністрація морських портів України» (далі АМПУ).

Mema cmammi. Основною метою даного дослідження $є$ аналіз майнового стану, результатів діяльності та ефективність державної політики розвитку морських портів України.

Виклад основного матеріалу дослідження. Морський транспорт займає важливе місце серед підгалузей транспортного сполучення у зв'язку із особливим значенням у зовнішньоекономічній діяльності, великою часткою іноземного елемента та наявністю міжнародно-правового регулювання. 
До складу морського транспорту входять підприємства морського транспорту, що здійснюють перевезення пасажирів і вантажів, порти і пристані, судна, судноремонтні заводи, морські шляхи сполучення та інші підприємства, установи та організації незалежно від форм власності, що забезпечують роботу морського транспорту.

3 метою управління морським транспортом, в результаті проведених реформ, в 2013 році створено Державне підприємство «Адміністрація морських портів України» (АМПУ) для управління державним майном в морських портах країни і його ефективного використання, створення механізмів для залучення інвестицій в портову інфраструктуру для ії розвитку і стабільної роботи бізнесу, а також підтримка паспортних глибин акваторій портів, забезпечення безпеки мореплавства та ін.

ДП «Адміністрація морських портів України» забезпечує функціонування морських портів, стягує портові збори, надає послуги загального технічного обслуговування. Володіє стратегічними об'єктами портової інфраструктури, до яких належать акваторії морських портів, гідротехнічні споруди, причали й інфраструктура загального користування (під'їзні дороги, інженерні мережі). У кожному морському порту діє філія ДП «АМПУ» (адміністрація морського порту).

Основною метою функціонування підприємства $є$ можливість сприяти розвитку морської транспортної інфраструктури України та підвищенню конкурентоспроможності українських морських портів шляхом проведення адміністративної реформи та створення умов i механізмів для залучення інвестицій.

Основними цілями підприємства є:

- забезпечення функціонування морських портів;

- організація та забезпечення безпеки судноплавства;

- зберігання, ефективне використання і розвиток державного майна, закріпленого за АМПУ на праві господарського ведення та отримання прибутку [9].

Згідно «Стратегії розвитку морських портів України на період до 2038 року» морський транспортний комплекс $є$ багатофункціональною структурою, що задовольняє потреби національної економіки у транспортному забезпеченні [10].

Кабінет міністрів погодив пропозицію Міністерства інфраструктури про внесення ДП «Адміністрація морських портів України» (АМПУ) до переліку об'єктів, які не підлягають приватизації, але можуть бути корпоратизовані [11]. Для реалізації корпоратизації АМПУ необхідно розглянути можливість передачі до статутного капіталу підприємства причалів, що істотно розширить можливості АМПУ щодо ефективного використання та розвитку портової інфраструктури. Корпоративна система управління, вибудувана за найкращими світовими стандартами, і публічна звітність зроблять підприємство максимально відкритим i зрозумілим для міжнародних партнерів, фінансових установ, держави і суспільства. Корпоратизація АМПУ має відкрити нові можливості із залучення приватних інвестицій i додаткових коштів для реалізації інфраструктурних проектів в портах. 
АМПУ входить в сферу управління Міністерства інфраструктури України і об'єднує українські морські порти та інші інфраструктурні елементи, одночасно сприяючи розвитку i конкурентоспроможності кожного 3 них. Структура підприємства складається 3 центрального офісу в Києві і головного представництва в Одесі, філії «Дельта-Лоцман» та 13 філій в морських портах України.

На сьогодні АМПУ - це:

- підприємство 3 активами понад 21 млрд грн;

- другий найбільший судновласник країни (128 одиниць флоту);

- один 3 найбільших платників податків в державний бюджет (4,66 млрд грн в 2016 році);

- 263 причали загальною протяжністю понад 40 км;

- 131 млн тонн перевантажених вантажів;

- 650 млн гривень капітальних інвестицій [9].

Розглянемо майновий стан ДП «АМПУ» на прикладі даних таблиці 1. Як видно 3 даних таблиці 1, первісна вартість основних засобів на кінець року за період 2013-2017 років зросла на 3,37 млрд грн. При цьому залишкова вартість збільшилася на 1,79 млрд грн, що викликано зростанням суми зносу на 1,58 млрд. грн.

Таблиця 1

Майновий стан Державного підприємства «Адміністрація морських портів України» в 2013-2017 роках

\begin{tabular}{|l|c|c|c|c|c|c|}
\hline \multicolumn{1}{|c|}{ Показник } & \multicolumn{5}{|c|}{ Роки } & $\begin{array}{c}2017 \text { р. до } \\
2013 \text { p. } \\
(+/-)\end{array}$ \\
\cline { 2 - 7 } & 2013 & 2014 & 2015 & 2016 & 2017 & 157352,2 \\
\hline $\begin{array}{l}\text { Первісна вартість } \\
\text { основних засобів на } \\
\text { початок року }\end{array}$ & 0 & 155042,9 & 156831,8 & 157152,6 & 157352,2 & 1537,3 \\
\hline $\begin{array}{l}\text { Первісна вартість } \\
\text { основних засобів на } \\
\text { кінець року }\end{array}$ & 155042,9 & 156831,8 & 157152,6 & 157352,2 & 158414,2 & 337,8 \\
\hline $\begin{array}{l}\text { Середньорічна } \\
\text { вартість основних } \\
\text { засобів, млн. грн. }\end{array}$ & 77521,5 & 155937,4 & 156992,2 & 157252,4 & 157883,2 & 80361,8 \\
\hline $\begin{array}{l}\text { Знос основних засобів } \\
\text { на кінець року, млн. } \\
\text { грн. }\end{array}$ & 143252,6 & 143616,5 & 144136,5 & 144468,8 & 144828,3 & 1575,7 \\
\hline $\begin{array}{l}\text { Залишкова вартість } \\
\text { основних засобів на } \\
\text { кінець року, млн. грн. }\end{array}$ & 11790,3 & 13215,3 & 13016,1 & 12883,4 & 13585,9 & 1795,6 \\
\hline Коефіціснт зносу & 0,92 & 0,92 & 0,92 & 0,92 & 0,91 & $-0,01$ \\
\hline $\begin{array}{l}\text { Коефіціснт } \\
\text { придатності }\end{array}$ & 0,08 & 0,08 & 0,08 & 0,08 & 0,09 & 0,01 \\
\hline
\end{tabular}


Продовження табл. 1

\begin{tabular}{|l|c|c|c|c|c|c|}
\hline $\begin{array}{l}\text { Всього майна на кінець } \\
\text { року, млн. грн. }\end{array}$ & 16656 & 17481 & 20640 & 20683 & 21518 & 4861,5 \\
\hline $\begin{array}{l}\text { Основні засоби у \% до } \\
\text { майна }\end{array}$ & 70,79 & 75,60 & 63,06 & 62,29 & 63,14 & $-7,6$ \\
\hline $\begin{array}{l}\text { Оборотні засоби на } \\
\text { кінець року, млн. грн. }\end{array}$ & 1094,60 & 1322,40 & 4372,70 & 4228,00 & 3845,90 & 2751,3 \\
\hline $\begin{array}{l}\text { Оборотні засоби у \% до } \\
\text { майна }\end{array}$ & 6,6 & 7,6 & 21,2 & 20,4 & 17,9 & 11,3 \\
\hline $\begin{array}{l}\text { Відношення основних } \\
\text { засобів (залишкова } \\
\text { вартість) до оборотних } \\
\text { на кінець року }\end{array}$ & 10,8 & 10,0 & 3,0 & 3,1 & 3,5 & $-7,2$ \\
\hline \multicolumn{1}{|c|}{ Розраховано авпоро, } \\
\hline
\end{tabular}

Розраховано автором за даними [9]

Незадовільним є факт великого коефіцієнту зносу основних засобів, що склався на рівні 0,92 на протязі 2013-2016 років та дещо зрісши в 2017 році, що вказує на значну зношеність матеріально-технічної бази портів. Питома вага основних засобів у майні підприємства в 2014 році становила більше $75 \%$ та скоротившись до 63\% в 2017 році. Відсоток оборотних засобів навпаки зріс, найвищого рівня досягнувши в 2015 році $(21,2 \%)$, що викликано зростанням сум грошових коштів, що наявні у балансі підприємства в розмірі 3,3 млрд грн в 2015 році. поступово скорочуючись в наступних досліджуваних роках і в звітному році склавши - 2,45 млрд грн.

Значну частину вантажів приймають 4 морських порти, серед яких однозначне лідерство займає морський порт «Южний», на що вказує рисунок 1.
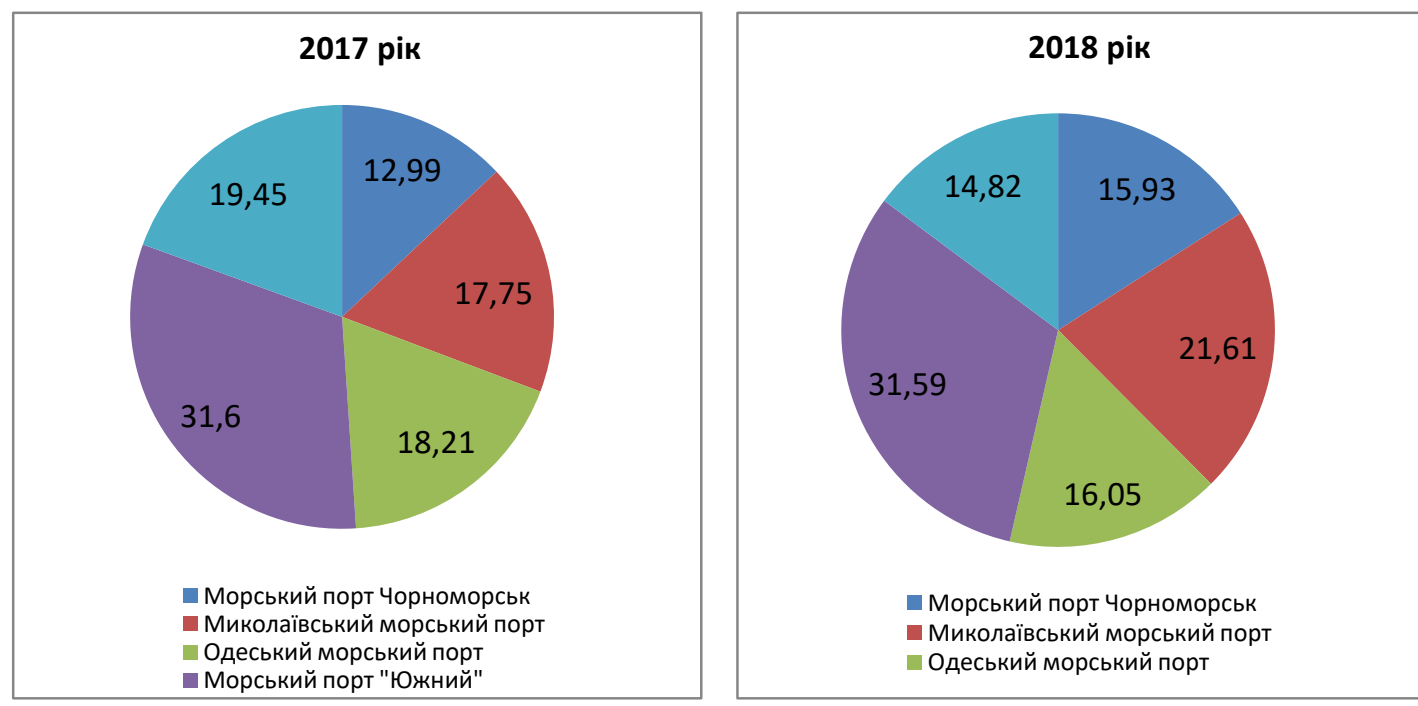

Рис. 1. Питома вага портів у переробці вантажів в 2017 та 2018 роках

Як видно з рисунку 1, в 2018 році питома вага основних чотирьох портів складає більше 85\% і лише 15\% припадає на інші 9 портів України. Найбільший відсоток у перевалці вантажів займає морський порт «Южний» - 31,6\% в 2017 та 2018 роках. На 4 відсоткових пункти зросла питома вага Миколаївського 
морського порту, який в 2018 році зайняв другу позицію у обробці вантажів, потіснивши 3 цього місця Одеський морський порт, який в 2017 році займав дане місце з питомою вагою 18,21\%. Чорноморський морський порт, хоча і займає четверту позицію в обсягах обробки вантажів, але за 2018 рік збільшивши свою питому вагу на 3 відсоткових пункти. 3 даних рисунку можна зробити висновок, що найбільш динамічно розвиваючими портами $є$ Миколаївський морський порт та морський порт Чорноморський. Одеський морський порт навпаки має негативну динаміку по скороченню обсягів обробки вантажів

Розглянемо обсяги обробки вантажів у всіх портах, що підпорядковуються АМПУ в 2017-2018 роках (рис. 2).

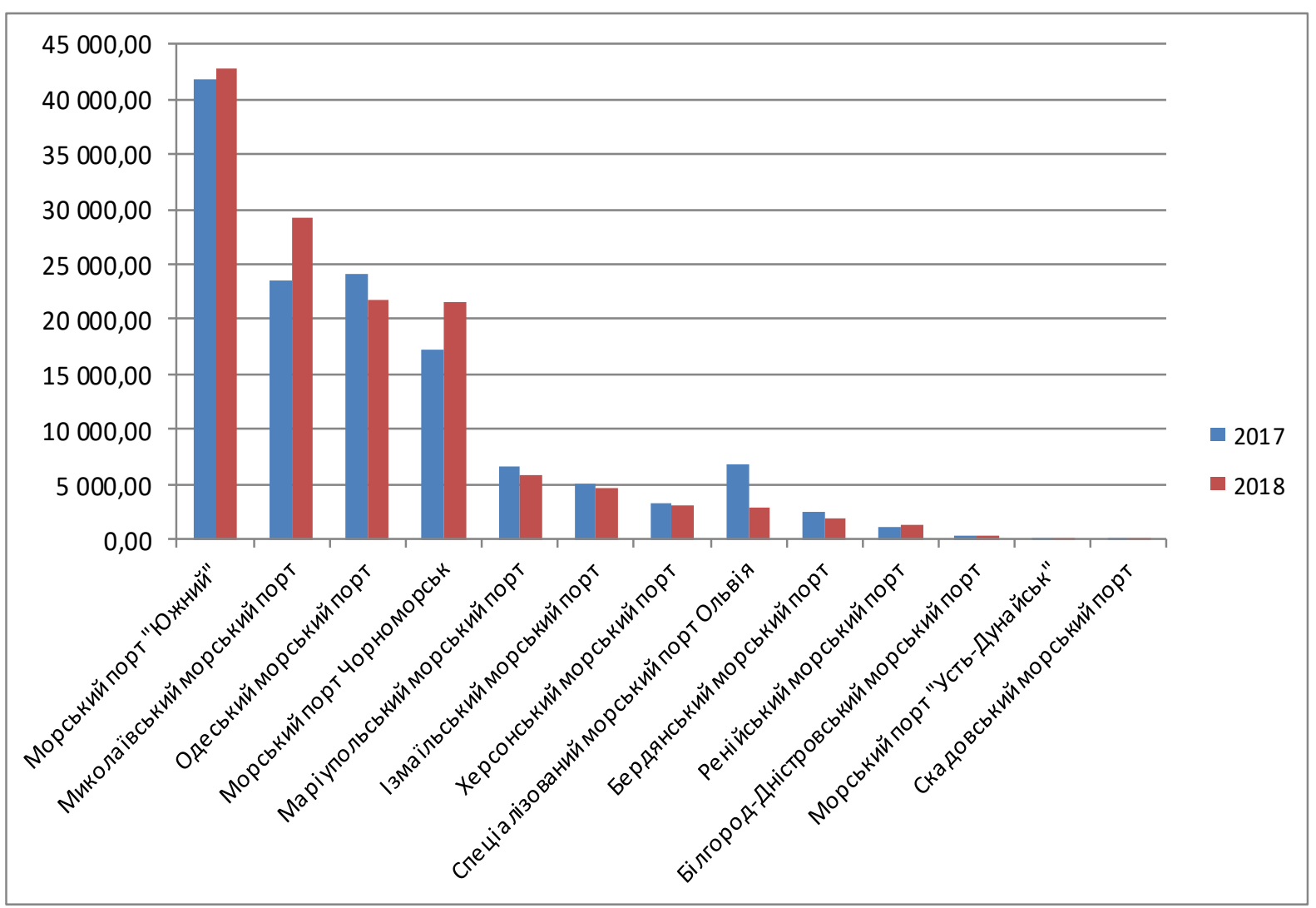

Рис. 2. Обсяги обробки вантажів в морських портах АМПУ в 2017-2018 роках

Як видно з рисунку 2, більш дрібні порти мають негативну динаміку по скороченню обсягів обробки вантажів в 2017-2018 роках. Більш ніж двохразове скорочення спостерігаємо в спеціалізованому морському порту Ольвія.

Номенклатура оброблених товарів в морських портах, що наведена в таблиці 2, має важливе значення при розробці інвестиційних програм розвитку портів.

Дані таблиці 2 вказують на загальне зростання обробки вантажів в 2018 році порівняно з 2016 роком на $2,6 \%$, що відбулося в основному за рахунок збільшення обсягів обробки тарно-штучних вантажів, обсяг яких зріс на 11,4\% та підвищенні обсягів суховантажних сипучих вантажів - на 1\%. Натомість відбулося скорочення переробки наливних вантажів на 5,2\%, в основному нафтопродуктів та хімічних вантажів, які зменшилися на 42,1 та $18,5 \%$ 
відповідно. Серед наливних вантажів зросли обсяги обробки олії та нафти $(17,7$ та 13,7\% відповідно).

Таблиця 2

Номенклатура обробки вантажів морськими портами в 2016-2018 роках

\begin{tabular}{|c|c|c|c|c|c|}
\hline \multirow{2}{*}{ Показник } & \multicolumn{3}{|c|}{ Всього по морським портам } & \multicolumn{2}{|c|}{2018 р. до 2016 р. } \\
\hline & 2016 & 2017 & 2018 & $+/-$ & $\%$ \\
\hline ВСЬОГО ВАНТАЖІВ & 131745,9 & 132578,44 & 135171,07 & 3425,17 & 102,60 \\
\hline НАЛИВНІ & 10788,6 & 11016,26 & 10223,45 & $-565,15$ & 94,76 \\
\hline Нафта & 591,6 & 1011,62 & 672,72 & 81,12 & 113,71 \\
\hline Нафтопродукти & 2226,7 & 1851,32 & 1287,88 & $-938,82$ & 57,84 \\
\hline Олія & 4709,9 & 5544,75 & 5543,70 & 833,80 & 117,70 \\
\hline Хімічні & 3203,8 & 2544,48 & 2610,66 & $-593,14$ & 81,49 \\
\hline Інші наливні вантажі & 56,6 & 64,09 & 108,49 & 51,89 & 191,68 \\
\hline СУХОВАНТАЖНІ СИПУЧІ & 93413,4 & 95745,71 & 94270,91 & 857,51 & 100,92 \\
\hline Вугілля & 6075,4 & 10814,79 & 8103,14 & 2027,74 & 133,38 \\
\hline Кокс & 344,5 & 332,11 & 504,55 & 160,05 & 146,46 \\
\hline Руда всяка & 32719,9 & 27464,13 & 28061,30 & $-4658,60$ & 85,76 \\
\hline Будівельні & 4089,5 & 5867,32 & 4633,00 & 543,50 & 113,29 \\
\hline Хімічні, мінеральні добрива & 2080,9 & 1022,31 & 969,79 & $-1111,11$ & 46,60 \\
\hline Цукор & 69,2 & 16,23 & - & $-69,20$ & - \\
\hline Хлібні - всього & 40347 & 40651,20 & 41380,11 & 1033,11 & 102,56 \\
\hline з них зерно & 39448 & 39155,82 & 40321,89 & 873,89 & 102,22 \\
\hline Інші сипучі вантажі & 7687 & 9574,60 & 10619,02 & 2932,02 & 138,14 \\
\hline ТАРНО-ШТУЧНІ ВАНТАЖІ & 27543,9 & 25816,47 & 30676,71 & 3132,81 & 111,37 \\
\hline Автотехніка й сільгосптехніка & 34,3 & 52,18 & 55,05 & 20,75 & 160,50 \\
\hline Лісні вантажі & 593,1 & 418,96 & 362,20 & $-230,90$ & 61,07 \\
\hline Чорні метали - всього & 16678,1 & 14816,09 & 16081,68 & $-596,42$ & 96,42 \\
\hline 3 них - чавун & 2631,5 & 2278,27 & 3118,50 & 487,00 & 118,51 \\
\hline - металопрокат & 11574,7 & 9761,37 & 9776,47 & $-1798,23$ & 84,46 \\
\hline - брухт & 186,4 & 86,33 & 90,08 & $-96,32$ & 48,33 \\
\hline - інші вантажі чорних металів & 2285,5 & 2690,12 & 3096,63 & 811,13 & 135,49 \\
\hline Хім.та мін. добрива & 38,7 & 132,76 & 217,26 & 178,56 & 561,40 \\
\hline Цемент в тарі & 1,1 & 4,40 & 12,34 & 11,24 & 1121,82 \\
\hline Пром.товари в ящиках і кіпах & 3,1 & 8,85 & 11,68 & 8,58 & 376,77 \\
\hline Продовольчі вантажі - всього & 206,3 & 268,81 & 194,46 & $-11,84$ & 94,26 \\
\hline 3 них - швидкопсовні вантажі & 95,3 & 99,71 & 140,36 & 45,06 & 147,28 \\
\hline Контейнери(тонн) & 7887,6 & 7882,61 & 10934,59 & 3046,99 & 138,63 \\
\hline Контейнери(шт) & 389937 & 391768 & 535420 & 145483,00 & 137,31 \\
\hline Контейнери(теи) & 579472 & 590267,00 & 846485,00 & 267013,00 & 146,08 \\
\hline $\begin{array}{l}\text { Автомобілі великовантажні } \\
\text { (тонн) }\end{array}$ & 1078,7 & 1208,60 & 1831,34 & 752,64 & 169,77 \\
\hline $\begin{array}{l}\text { Автомобілі великовантажні } \\
\text { (шт) }\end{array}$ & 31491 & 36669 & 59972 & 28481,00 & 190,44 \\
\hline Інші тарно-штучні вантажі & 1023,1 & 1023,21 & 976,11 & $-46,99$ & 95,41 \\
\hline
\end{tabular}

Розраховано автором за даними [9]

Найбільшого зростання серед суховантажних сипучих вантажів зазнала переробка коксу $(46,5 \%)$, вугілля $(33,4 \%)$ та інших сипучих вантажів $(38,1 \%)$. 
Зростання обробки тарно-штучних вантажів обумовлено значним збільшенням контейнерних перевезень, що у відносному виразі складає 38,6\%. Також відбулося зростання перевезень автомобілів великовантажних (69,8\%) та хімічних і мінеральних добрив (5,6 рази). Натомість скоротилася переробка чорних металів (3,6\%) та лісних вантажів (39\%).

В абсолютному виразі найбільшого зростання зазнала обробка контейнерів, обсяг яких у вазі зріс на 3046,99 тис. тонн, інших сипучих вантажів (2932 тис. тонн), вугілля (2027,74 тис. тонн) та хлібних вантажів.

Наявні засоби АМПУ дозволяють вести ефективну діяльність, отримуючи щороку значні суми прибутків, що видно $з$ даних таблиці 3.

Таблиця 3

Фінансові результати діяльності Державного підприємства «Адміністрація морських портів України» в 2013-2017 роках

\begin{tabular}{|c|c|c|c|c|c|c|c|}
\hline \multirow[b]{3}{*}{ Показники } & \multicolumn{5}{|c|}{ Роки } & \multirow{2}{*}{\multicolumn{2}{|c|}{$\begin{array}{c}\text { Відхилення } \\
2017 \text { до } \\
2013 \text { рр. }\end{array}$}} \\
\hline & \multirow[b]{2}{*}{2013} & \multirow[b]{2}{*}{2014} & \multirow[b]{2}{*}{2015} & \multirow[b]{2}{*}{2016} & \multirow[b]{2}{*}{2017} & & \\
\hline & & & & & & тис. грн & $\%$ \\
\hline $\begin{array}{l}\text { Чистий доход } \\
\text { (виручка) від } \\
\text { реалізації } \\
\text { продукції } \\
\text { (товарів, робіт, } \\
\text { послуг) }\end{array}$ & 1870928 & 4002291 & 6810663 & 7297604 & 7633560 & 5762632 & 408,0 \\
\hline $\begin{array}{l}\text { Собівартість } \\
\text { реалізованої } \\
\text { продукції } \\
\text { (товарів, робіт, } \\
\text { послуг) } \\
\end{array}$ & 826932 & 1396365 & 1946733 & 2633760 & 2751164 & 1924232 & 332,7 \\
\hline $\begin{array}{l}\text { Валовий: } \\
\text {-прибуток }\end{array}$ & 1043996 & 2605926 & 4863930 & 4663844 & 4882396 & 3838400 & 467,7 \\
\hline $\begin{array}{l}\text { Інші операційні } \\
\text { доходи }\end{array}$ & 111094 & 473135 & 1037161 & 844692 & 680653 & 569559 & 612,7 \\
\hline $\begin{array}{l}\text { Адміністративні } \\
\text { витрати }\end{array}$ & 147488 & 303808 & 342734 & 452806 & 534567 & 387079 & 362,4 \\
\hline Витрати на збут & 1747 & 28 & - & - & - & -1747 & - \\
\hline $\begin{array}{l}\text { Інші операційні } \\
\text { витрати }\end{array}$ & 139958 & 363875 & 542983 & 588100 & 671233 & 531275 & 479,6 \\
\hline $\begin{array}{l}\text { Фінансові } \\
\text { результати від } \\
\text { операційної } \\
\text { діяльності: } \\
\text {-прибуток }\end{array}$ & 865897 & 2411350 & 5015374 & 4467630 & 4357249 & 3491352 & 503,2 \\
\hline $\begin{array}{l}\text { Інші фінансові } \\
\text { доходи }\end{array}$ & - & 3406 & 109607 & 219047 & 73449 & 73449 & - \\
\hline Інші доходи & 3400 & 12634 & 116697 & 120462 & 13571 & 10171 & 399,1 \\
\hline
\end{tabular}


Продовження табл.3

\begin{tabular}{|l|c|c|c|c|c|c|c|}
\hline $\begin{array}{l}\text { Фінансові } \\
\text { витрати }\end{array}$ & 48 & - & - & - & - & -48 & - \\
\hline Інші витрати & 1438 & 577022 & 514389 & 101889 & 1208 & -230 & 84,0 \\
\hline $\begin{array}{l}\text { Фінансові } \\
\text { результати від } \\
\text { звичайної } \\
\begin{array}{l}\text { діяльності: } \\
\text {-прибуток }\end{array}\end{array}$ & 867811 & 1850368 & 4727289 & 4705250 & 4443061 & 3575250 & 512,0 \\
\hline $\begin{array}{l}\text { Витрати 3 } \\
\text { податку на } \\
\text { прибуток }\end{array}$ & 220658 & 339316 & 879997 & 850881 & 837474 & 616816 & 379,5 \\
\hline $\begin{array}{l}\text { Чистий: } \\
\text {-прибуток }\end{array}$ & 647153 & 1511052 & 3847292 & 3854369 & 3605587 & 2958434 & 557,1 \\
\hline
\end{tabular}

Розраховано автором за даними [9]

Як видно з даних таблиці 3, чистий дохід від реалізації продукції (товарів, робіт, послуг) за період 2013-2017 років зріс в 4 рази, що викликано як зростанням обсягів робіт і послуг, що виконує державне підприємство так і зі зростанням вартості даних робіт. Собівартість реалізованої продукції (товарів, робіт, послуг) зростає повільнішими темпами, що призвело до збільшення показника валового прибутку в 4,7 рази. За рахунок значного зростання інших операційних доходів прибуток від операційної діяльності зріс в 5 разів, як i прибуток від звичайної діяльності. Чистий прибуток натомість досяг найбільш значної динаміки, збільшившись в 5,6 рази, що вказує на значне підвищення ефективності виробничо-господарської діяльності державного підприємства.

Такі переконливі фінансові результати діяльності ДП «АМПУ» певною мірою викликані збільшенням обсягів перевалки вантажів всіх господарюючих суб'єктів (табл. 2), що входять до складу державного підприємства.

Незважаючи на зростання прибутків, отримуваних АМПУ, зношеність основних фондів, що перевищує 90\%, не дозволяє розраховувати на подальшу ефективну роботу стивідорних компаній державної форми власності. Саме тому Кабінет Міністрів України, підтримавши пропозицію Міністерства інфраструктури України, затвердив зниження ставок портових зборів на 20\%, починаючи 31 січня 2018 року. Дане рішення стосується ставок корабельного, канального, маякового, санітарного, якірного, причального та адміністративного зборів. Цьому передувала робота по розробці методики розрахунку базової ставки, що передбачає перехід до нової бази справляння портових зборів грос-тоннаж (GT) і встановлення ставки корабельного збору за використання всіх частин акваторії (включаючи якірні стоянки, підхідні канали). При цьому скасовуються окремі якірний збір і канальний збір за рух підхідними каналами морських портів та терміналів.

Також передбачається, що, починаючи 31 січня 2018 року, виплата частини чистого прибутку, який відраховується ДП «Адміністрація морських портів України» до Державного бюджету буде здійснюватися у розмірі $50 \%$, що менше на 25\%, порівняно 3 попередніми періодами. 
Висновки і перспективи подальших досліджень. Морський господарський комплекс, що включає в себе порти, потребує реформ, спрямованих на удосконалення системи управління державними підприємствами шляхом переходу до корпоративної форми управління з 100\% акцій у власності держави. Врахування світового досвіду, удосконалення механізмів державного регулювання портового бізнесу, підвищення конкурентоспроможності галузі i ролі морського транспорту у використанні потенціалу міжнародних транспортних коридорів, забезпечення всім суб'єктам рівного доступу до об’єктів портової інфраструктури, а також корпоратизація дозволить відкрити нові можливості із залучення приватних інвестиційних ресурсів і додаткових коштів з метою удосконалення інфраструктури портів, що зношена більш, ніж на 90\%. Подальші дослідження в сфері залучення інвестицій в інфраструктурні проекти розвитку портового господарства дозволять удосконалити державні механізми.

\section{Лimepamypa:}

1. Цабієва Т. О. Забезпечення сталого функціонування i розвитку морських портів України: автореф. дис. ... канд. екон. наук: спец. 08.07.04. Одеса, 2005. $21 \mathrm{c.}$

2. Мірошко В. М. Стратегічне планування економічного розвитку вантажних портів України: автореф. дис. ... канд. екон. наук: спец. 08.00.03. Львів, 2007. 20 с.

3. Ільченко С. В. Організаційно-економічні основи інституціонального реформування морських портів: автореф. дис. ... канд. екон. наук: спец. 08.00.04. Одеса, 2007. 20 c.

4. Меркт О. В. Методичні засади стратегії розвитку морських торговельних портів у конкурентному середовищі: автореф. дис. ... канд. екон. наук: 08.07.04. Київ. нац. авіац. ун-т. К., 2002. 16 с.

5. Карпенко О. О., Продченко Ю. Г. Аналіз транзитних перевезень вантажів через морські торгівельні порти України. Вод. транспорт. 2012. Вип. 2. C. $123-128$.

6. Kopylenko, O., Gryshova, I., Diachenko, O. (2018). Leading institutional mechanism of the state regulation and the shadow economy. In: Strielkowski, W. (ed.). Proceedings of the 2nd International Conference on Social, Economic and Academic Leadership (ICSEAL 2018), Advances in Social Science, Education and Humanities Research, vol. 217, pp. 60-68. doi: 10.2991/icseal-18.2018.10.

7. Гришова І. Ю., Дяченко О. П. Стратегія державної політики у сфері детенізації економіки України. Право та державне управління. 2016. № 3. C. $183-190$.

8. Гришова I. Ю., Дяченко О. П. Дієвість механізмів державного управління у сфері протидії тіньовій економіці в Україні. Право та державне управління. 2016. № 3. С.183-190.

9. Офіційний сайт Державного підприємства «Адміністрація морських портів України». URL: http://www.uspa.gov.ua. 
10. Про затвердження Стратегії розвитку морських портів України на період до 2038 року: розпорядження КМУ №548-р від 11.07.2013 p. URL: https://zakon.rada.gov.ua/laws/show/548-2013-\%D1\%80.

11. Про погодження пропозиції щодо реорганізації державних підприємств морського транспорту: Розпорядження Кабінету Міністрів України №133-p від 04.03.2013p. URL: https://zakon.rada.gov.ua/laws/show/133-2013$\% \mathrm{D} 1 \% 80$.

References:

1. T. O. Tsabiieva, (2005) "Zabezpechennia staloho funktsionuvannia i rozvytku mors'kykh portiv Ukrainy" : avtoref. dys. kand. ekon. nauk : spets. 08.07.04. Odesa.

2. V. M. Miroshko, (2007) "Stratehichne planuvannia ekonomichnoho rozvytku vantazhnykh portiv Ukrainy” : avtoref. dys. kand. ekon. nauk : spets. 08.00.03. L'viv.

3. S. V. Il'chenko, (2007) "Orhanizatsijno-ekonomichni osnovy instytutsional'noho reformuvannia mors'kykh portiv" : avtoref. dys. kand. ekon. nauk : spets. 08.00.04. Odesa.

4. O. V. Merkt, (2002) "Metodychni zasady stratehii rozvytku mors'kykh torhovel'nykh portiv u konkurentnomu seredovyschi": avtoref. dys. kand. ekon. nauk: 08.07.04. Kyiv.

5. O. O. Karpenko, Yu. H. Prodchenko, (2012) Analiz tranzytnykh perevezen' vantazhiv cherez mors'ki torhivel'ni porty Ukrainy, Vodnyj transport, vol. 2, pp. 123128.

6. O. Kopylenko, I. Gryshova, O. Diachenko, (2018). Leading institutional mechanism of the state regulation and the shadow economy. In: Strielkowski, W. (ed.). Proceedings of the 2nd International Conference on Social, Economic and Academic Leadership (ICSEAL 2018), Advances in Social Science, Education and Humanities Research, vol. 217, pp. 60-68. doi: 10.2991/icseal-18.2018.10.

7. I. Yu. Hryshova, O. P. Diachenko, (2016) "Stratehiia derzhavnoi polityky u sferi detenizatsii ekonomiky Ukrainy", Pravo ta derzhavne upravlinnia, vol. 3, pp. $183-190$.

8. I. Yu. Hryshova, O. P. Diachenko, (2016) Diievist' mekhanizmiv derzhavnoho upravlinnia u sferi protydii tin'ovij ekonomitsi v Ukraini, Pravo ta derzhavne upravlinnia, vol 3, pp. 183-190.

9. Official site of the State Enterprise "Administration of Seaports of Ukraine", available at: http://www.uspa.gov.ua.

10. Cabinet of Ministers of Ukraine (2013), "Resolution of the Cabinet of Ministers of Ukraine "On Approval of the Strategy for the Development of Seaports of Ukraine for the Period until 2038", available at: https://zakon.rada.gov.ua/ laws/show/548-2013-\%D1\%80

11. Cabinet of Ministers of Ukraine (2013), "Resolution of the Cabinet of Ministers of Ukraine "On approval of the proposal for the reorganization of state enterprises of maritime transport", available at: https://zakon.rada.gov.ua/ laws/show/133-2013-\%D1\%80 
The state policy for the development of seaports should be aimed at creating a transparent system of public-private partnership, which will allow the private sector to invest in modernization and construction of port facilities of state importance.

In the conditions of globalization of the world economy and the expansion of integration processes, it became necessary to study the mechanisms of state policy in relation to improving the efficiency of the operation of seaports, which requires a thorough analysis of the state and results of activities of the State Enterprise "Administration of Seaports of Ukraine" in recent years.

The article analyzes the property situation, which is characterized by significant depreciation of fixed assets and their significant prevalence over working capital. The results of activity of seaports on cargo processing in terms of their nomenclature indicate the growth of processing of such goods as: coke, coal, other bulk cargo and container transport.

Having defined the structure of cargo transportation through separate seaports that are part of the State Enterprise "Administration of Seaports of Ukraine", it can be noted that 4 main ports handle more than $85 \%$ of goods: the port "Yuzhny", Mykolaiv, Odesa and the Black Sea seaports.

The financial results of the state enterprise, which manages the state property in the seaports, are calculated, and based on these, the necessity of introducing maritime reform with the attraction of private investments is grounded. The net profit of the state-owned enterprise increased 5.6 times, indicating a significant increase in the efficiency of the state-owned enterprise's production and economic activity.

The maritime economic complex, including ports, requires reforms aimed at improving the governance system of state-owned enterprises through the transition to a corporate form of management with $100 \%$ state-owned shares. Taking into account world experience, improving the mechanisms of state regulation of the port business, increasing the competitiveness of the industry and the role of maritime transport in using the potential of international transport corridors, providing all actors with equal access to port infrastructure objects, as well as corporatization will open new opportunities for attracting private investment resources and additional funds to improve the infrastructure of ports, which is worn by more than $90 \%$. Further research in the field of attracting investments in infrastructure projects for the development of the port economy will improve the state mechanisms. 